\title{
Studies on the Biological Action of Human Placental Lactogen (hPL) during Pregnancy
}

\author{
Yoshiko TANAKA \\ Department of Obstetrics and Gynecology, Kobe University, School of Medicine, \\ Kobe, Japan (Director : Professor Shimpei Tojo, M.D.)
}

In the previous reports, it was demonstrated that hPL had the remarkable promoting action on lipolysis, glucose uptake of the adipose tissue and insulin secretion in vivo.

The purpose of this paper is to describe the results of the studies on the biological action of this hormone during pregnancy in detail.

First, in the preliminary experiment, the author examined the effect of hPL on the foetal growth in utero.

Namely, by the continuous administration of the various doses of hPL to the pregnant rats, the significant increase in the content of glucose, free fatty acid (FFA), triglyceride (TG), total nitrogen (T-N) and body weight of the foetuses was noted.

At the next step of experiment, in order to know this effect of hPL in the foeto-placental maternal system, the maternal adipose tissue was labeled with oleic acid-1- $\mathrm{G}_{14}$, and four hours after the administration of hPL, $\mathrm{G}_{14}$-FFA and cold FFA of maternal blood and foetal carcass, and $\mathrm{C}_{14}$-TG of maternal fat tissue and foetal carcass were measured.

$\mathrm{C}_{14}$-FFA and cold FFA of blood and $\mathrm{C}_{14}$-TG of fat tissue increased remarkably in the mother rats treated with hPL and, at the same time, the foetuses from the hPL treated mother rats showed also the marked increase in $\mathrm{C}_{14}$-FFA and $\mathrm{C}_{14}$-TG content.

In the other experiment, the pregnant rats on $\mathrm{L}_{16}$ (16th day of pregnancy) were injected with hPL following the pretreatment with D-glucose- $\mathrm{G}_{14}$, and then $\mathrm{G}_{14}$-glucose and cold glucose in the foetal liver were estimated.

As the result, the concentration of $\mathrm{C}_{14}$-glucose and cold glucose of the foetal liver was about two times as high as that of the foetuses from the control rats.

On the other had, the suspected immediate action of hPL on the foetuses was studied also with direct injection of it to the foetuses in one uterine horn using them in another horn as the control.

Furthermore, the author measured and compared the activities of lipoprotein lipase (L.P.L.) and hormone sensitive lipase (H.S.L.) of the foetuses, new borns and adult rats.

With the direct intraperitoneal administration of hPL to the foetuses in utero, the author could not find any remarkable change in the content of glucose, FFA, TG and serum T-N of the foetuses, even four hours after the injection.

Moreover, the activities of both lipases in foetuses were lower than those in newborns or adult rats. 
From these experimental results, the following conclusion might be drawn: hPL secreted from the placenta affects primarily the maternal metabolism of carbohydrate and fat (glucose-fatty acid cycle), and induces hyperlipemia and hyperglycemia which influence the foetal metabolism via placenta.

The transported carbohydrate might be utilized as an energy source, but on the other hand, FFA might be utilized for synthesis of neutral fat of the foetus.

Furthermore, suspectedly, amino acids transported into the foetus through the placenta, might participate in protein synthesis in cooperation with hydrogen ion from glycolysis and actions of pituitary growth hormone, insuline etc.

In conclusion, hPL effects primarily the metabolism, especially glucose-fatty acid cycle of the maternal body, which supplies very important materials (FFA and glucose etc.) to the foetus for his anabolic process in growth.

Namely, the author may be able to emphasize that hPL is one of the very important "metabolism regulating factors" during pregnancy.

(See pp. 698 715) 


\title{
妊娠時における hPLの生物学的意義に関する基礎的研究
}

\author{
神戸大学医学部産科婦人科学教室（主任 : 東條伸平教授） \\ 田 中 歓 子
}

（昭和47年 9 月19日受付）

HPL を妊娠ラットに連続的に投与し, 母体における glucose-fatty acid cycle の変化や胎仔の発育 状態を検討した結果，hPL により母体の glucose, FFA，TG，T-N 量が有意に増加し，しかもこの場 合胎仔の体重, 各臟器重量の有意な増加をも認めることができた.

HPL を子宮内胎仔に直接投与してもこれらの変化をひきおてすことはできなかつた．てれらのてと から hPL は妊娠中母体に対して直接作用する重要な「代謝調節ホルモン」であると考えられ, その作 用の一義的な場は placentomaternal unit にあり，てのホルモンにより上記の変化をうけた母体が胎盤 を介して胎児の発育に有用な同化資材を提供する可能性が推察できた。

\section{序論}

Human Placental Lactogen (hPL) 飞関する研究は伊藤, 東 (1961), Josimovich and MacLaren (1964) および Kaplan and Grumbach (1964) らによつて始められ，乙のホルモンは抗ヒト成長ホルモン血清と交叉 反応を示し，またヒト成長ホルモン $(\mathrm{hGH})$ やプロラクチン (hPRL) に似た生物活性をもつてとが明らか になつてきた。

このホルモンは胎艋で産生される単純蛋白体である。

HPL の分泌は妊娠後半期にたかまり，妊娠末期にむかつて著增するという特異なパターンを示すが，乙 のホルモンの妊娠個体におけを生物学的意義については今日なお見解が統一されておらず，妊娠に関する内 分泌あるいは代謝研究上の一つの焦点となつている.

すでに協同研究者村田 ${ }^{8}$ (1972) は hPL のもつ生物学的性格の一つとして，乙のホルモン自身が直接 adenyl cyclase の活性をたかめ, cyclic-AMP を介して脂肪組織中の hormone sensitive lipase (H.S.L.) を活性化するということ，つまり lipolytic action をもつてとを示し，乙の作用が弤娠時の母体における代 謝に影響を与え，間接的にしろ胎児の代謝発青に意義をもつのではななからうかと推察した。

そてで著者は，feto-placental maternal system におけるhPL の意義を「代謝調節ホルモン」としての あり方から検討すべく，特にこのホルモンが母体および胎児の糖質および脂質代謝にどのような影響を与省を， 胎児の発育にどのように関与するのかについて系統的な基礎的研究を行ない興味ある知兒を得たので報告す る.

\section{I 。研究計画と使用した hPL について}

\section{A. 研究計画}

Lipolytic action を中心として, hPL の生物学的性格が, feto-placental maternal system のうち placento-maternal unit でどのように発揮され，かつ妊娠個体の glucose-fatty acid cycle にどのような影響 をおよばすか，またそれが胎児の発育にどのように影響するかということを知る目的で，著者はまず Wistar 系妊娠ラットに妊娠のある時期から一定期間 hPL を連続投与し，その但清中の glucose, free-fatty acid (FFA), triglyceride (TG) ならびに total nitrogen (T-N) 量の变化を検討し，さらに hPL の投与をうけ 
た妊娠ラットの胎仔の体重, 身長, 臓器重量と臟器の glycogen 量, ならびに胎仔 carcass の glucose, FFA, TG と T-N 量を hPL 非投与母体胎仔のそれと比較検封した.

次いで hPL の連続投与をうけた母体と胎仔間の glycogen, FFA および TG 量の推移を知る目的で, 標識 oleic acid と標識 D-glucose を使用し, あらかじめ妊娠ラットの脂肪組織を標識したのちに被検妊娠 ラットに hPL を投与し, 母血清と脂肪組織ならびに胎仔 carcass につき cold および hot glucose, FFA および TG 量を比較検討した。

一方直接子宮内胎仔腹腔内に hPL を投与し, 胎仔, 母体の糖質ならびに脂質代謝に与える影響を検討した。

著者は, 以上の如く hPL の作用を placento-maternal unit と feto-placental unit の二つのユニットに つき先づ別個に検討し，その成績から妊娠時のいわゆる feto-placental maternal system における hPLの 生物学的意義を考察した。

\section{B. 使用した hPL について}

HPL には今日なお他の蛋白ペプタイドホルモンのような国際的標品がないため, hPL を使つた研究には， 研究者達が各自で製精した hPL か，あるいは 95/98\% pure Lederle Preparation Lot. \#prep. 4508-C75 の hPL を使用しているのが普通である.

そてで本章では著者が本実験に使用した hPL についてあらかじめ説明しておきたい，著者の使用した hPL は共同研究者の望月, 森川ら $\left(1970^{7)}, 1971^{30)}\right)$ によて, 新鮮末期胎盤から Friesen ${ }^{17)}(1966)$ の改 良法で抽出した粗 hPL を製精したものであつて，きわめて腩い純度を有しており，我々は本物質を hPLKobe と名づけている ${ }^{1) \sim 4}$.

この hPL-Kobe は, 7\%ポリアクリールアマイドディスク電気泳動法でシャープな単一バンドをしめし, hGH よりも強い酸性荷電傾向をもち, 超遠心分離法では均一な沈降像しめし, 沈降系数は, $\mathrm{S}_{20} \mathrm{w} 2,09$, 分 子量は約 25000 で, 酸性アミノ酸が主体をなし, 糖を含まない単純蛋白体である.

蛋白体としての立体構造は, 水素結合よりも結合力の弱酸性アミノ酸と塩基性アミノ酸間のイオン化結 合か, あるいは nonpolar アミノ酸間の hydrophobic 結合が主体をなすと考えられ，一鎖ペプチドの可能 性が強く, helix の少い平坦な構造をなしていると思われ，三次構造は恐らく，hPL一分子中に二個存在す る S-S 結合で決められるものであると考えられる。したがつて蛋白体としてはきわめて不安定である.

免疫学的性格としては，hGH と部分交叉反応をしめすものの，ヒトプロラクチン (hPRL) や䋐毛性性 腺刺激ホルモン (hCG) とはなんら交叉反応をしめさない.

また，乙れら hPL のもつ生物学的, 免疫学的雨活性基のうち, 生物活性基はN-末端に, 免没活性基は $\mathrm{G}$ 一末端に分離して存在するようである.

\section{II．妊娠ラットにおける hPL の作用}

\section{一母体への投与実験一}

\section{A. 実験材料之方法}

1. 実験材料

\section{i. HPL}

実験に使用した hPL は, hPL-Kobe. M•10-70 である.

なお，同一実験には同一バッチ番号の hPL-Kobe を使用するようにし，hPL-Kobe は 0.2\% glucose と $0.1 \% \mathrm{BSA}$ を含む pH 7.4 に調整された滅菌生理食塩水に $15 \mu \mathrm{g} / \mathrm{ml}, 50 \mu \mathrm{g} / \mathrm{ml}, 100 \mu \mathrm{g} / \mathrm{ml}$ となるようにそ れぞれ溶解し，小分けにして $-20^{\circ} \mathrm{C} て ゙$ 実験に使用するまで保存した.

\section{ii. 実験動物}

a. Wistar 系弤娠ラットとその胎仔

Wistar 系雌ラットをオリエンタル固形飼料を用いて恒温飼育室内で一定期間飼育し, 生活条件がほぼ一 定となつた体重 $150 \mathrm{gr}$ 前後のものを使用した。 またラットは, 胵スメア検査により, 精子の発見出来た日を 
Lo と定め, その妊娠初期と中期から，あるいは妊娠随時の時期に，妊娠ラットとその胎仔を実験に供した。

b. Sprague-Dawley (S.D.) 系妊娠ラットとその胎仔

標識 oleic acid を使用した実験には, 上述の Wistar 系妊娠ラット以外に, 体重 $350 \mathrm{gr}$ 前後の妊娠 $\mathrm{L}_{16}$ の S.D. 系ラットとその胎仔を使用した.

\section{2. 実験方法}

i. 胎仔の発育と胎仔および妊娠ラット血中の glucose, FFA, TG ならびに T-N 量におよぼす hPL の影響

ラット群別内わけ：

コントロール 1 群 ( 5 匹) : 滅菌生理食塩水 $1 \mathrm{ml}$ を一日量として $\mathrm{L}_{3}$ から $\mathrm{L}_{21}$ まで腹腔内へ連続投与した.

コントロール 2 群 $\left(5\right.$ 匹)：滅菌生理食塩水 $1 \mathrm{ml}$ を一日量として $\mathrm{L}_{3}$ から自然分婏日まで腹腔内へ連続投 与した.

A-1 群 ( 5 匹) : HPL $15 \mu \mathrm{g}$ を滅菌生理食塩水 $1 \mathrm{ml}$ にとかし，それを一日量として $\mathrm{L}_{3}$ から $\mathrm{L}_{21}$ まで 腹腔内一投与した。

A-2 群 ( 5 匹) : HPL $15 \mu \mathrm{g}$ を滅菌生理食塩水 $1 \mathrm{ml}$ にとかし，それを一日量として $\mathrm{L}_{10}$ から $\mathrm{L}_{21}$ まで 腹腔内一投与した。

B-1 群（ 5 匹）：HPL $50 \mu \mathrm{g}$ 在滅菌生理食塩水 $1 \mathrm{ml}$ にとかし，それを一日量として $\mathrm{L}_{3}$ から $\mathrm{L}_{21}$ まで 腹腔内一投与した。

B-2 群 ( 5 匹) : HPL $50 \mu \mathrm{g}$ を滅菌生理食塩水 $1 \mathrm{ml}$ にとかし，それを一日望として $\mathrm{L}_{10}$ から $\mathrm{L}_{21}$ まで 腹腔内へ投与した。

G-2 群 ( 5 匹) : HPL $100 \mu \mathrm{g}$ を滅菌生理食塩水 $1 \mathrm{ml}$ 飞とかし，それを一日量として $\mathrm{L}_{10}$ から $\mathrm{L}_{21}$ まで 腹腔内一投与した.

Wistar 系妊娠ラットを各 5 匹に群別し，前記の如くhPL および生理的食塩水をその腹腔内にそれぞれ 連続投与した，その後，コントロール 2 群は自然分婏直後の新生仔について，また他の群は $\mathrm{L}_{21}$ にエーテル 麻酔下で帝王切開によつて妊娠ラットよりとり出した新生仔について，その身長と体重ならびに肝臟，心藏， 腎臓などの藏器の重量を測定したあと, 胎仔 carcass の glucose, FFA, TG ならびに T-N 量と, 肝臓, 心藏および腎藏の glycogen 含有有を測定した.

一方血清中の glucose，FFA，TG と T-N 量は，分婏時子宮血管より採血した血清を利用して測定した。 Glycogen, FFA, TG ならびに T-N 量の測定方法は以下の如くである.

藏器の glycogen 含量：感度 $1 \mathrm{mg}$ までのトーションバランスでその重量を秤量した後， $30 \% \mathrm{KOH}$ を 用いる Good ${ }^{20)}$ (1932) の方法で glycogen を抽出し， $2 \mathrm{~N} \mathrm{H}_{2} \mathrm{SO}_{4}$ による加水分解で還元 glucose にしたあ と, Hoffman ${ }^{23)}$ (1937) ならびに Auto Analyzer Technicon Laboratory 法 ${ }^{24)}$ (1965) で測定した.

胎仔 carcass の glucose 量: 胎仔の体重を測定した後, シャーレ中で細断し冷生理食塩水 $2 \mathrm{ml}$ を加えて Potter-Elvehjem 型 homogenizer で homogenize した後，その homogenateの上清について Hoffman な らびに Auto Analyzer Technicon Laboratory 法で測定した。 また，母血清中の glucose 量は，血清から 直接 Hoffman ならびに Auto Analyzer Technicon Laboratory 法で測定した。

FFA 量：胎仔 carcass については前述の homogenate $1 \mathrm{ml}$ から，母体ではその血清 $1 \mathrm{ml}$ から，イソプ ロピルアルコールを基質とした混合抽出溶液（イソプロピルアルコール 40 : ヘプタン $10: 1 \mathrm{~N}_{2} \mathrm{HO}_{4}$ 1) でFFA を抽出した後, Dole ${ }^{13)}$ (1956) の変法で測定した。

TG 量：胎仔 carcass では homogenate $1 \mathrm{ml}$ から, 母体ではその血清 $1 \mathrm{ml}$ から Bloor の抽出溶液 (エ夕 ノール 3:エーテル 1v/v) で TG を抽出したあと,Fletcher のアセチルアセトン法 ${ }^{14)}(1968)$ にて測定した. $\mathrm{T}-\mathrm{N}$ 量：胎仔 carcass では homogenate $1 \mathrm{ml}$ を，母体ではその血清 $1 \mathrm{ml}$ について Koch and Hanke ${ }^{27)}$ （1948）の方法で測定した.

胎仔各藏器の重量については, 前記のトーションバランスで各臓器の湿重量を測定した後, 各臟器を凍結 
乾燥し同様にそれらの重量を測定した.

\section{ii. 母体および胎仔の glucose, FFA ならびに TG 量の変化に与える hPL の影響}

a. Wistar 系妊娠ラットに oleic acid-1- $\mathrm{C}_{14}$ を使用した場合

日本放射性同位元素領布の oleic acid-1-G 14 Lot. No. 248-14, $100 \mu \mathrm{Ci}$ につき，溶媒のベンゼンを flash Evaporator で蒸発乾固させたあと, 減菌生理食塩水けんだく混合溶液 (cold oleic acid $0.2 \%$, glucose 0.1 $\%$, BSA $0.1 \%$ ） $2 \mathrm{ml}$ を用いて emulsion とし，てれを12時間絶食させた妊娠 $\mathrm{L}_{16}$ の Wistar 系ラット（体 重 $200 \mathrm{gr}$ 前後).の尾静脈より注入した. hot oleic acid 投与後, 12匹のそれら処置ラットのうち4匹は 6 時間目にと殺し直ちに血液および子宮周囲の脂肪組織を採取してれをコントロール 1 とした. 一方他の 8 匹 の処置ラットのうち 4 匹は， $\mathrm{C}_{14}$-oleic acid 投与後 6 時間目にさらに 1 匹あたり hPL $100 \mu \mathrm{g}$ を尾静脈より 注入し，その後 4 時間目にと殺して血清および脂肪組織と胎仔を採取し，残りの 4 匹はコントロール 2 とし $\tau$ hot oleic acid 投与後10時間目にと殺し同様の測定に供した.

母血清および胎仔 carcass 中の cold glucose, FFA ならびに TG 量は, II-2-i に記述した方法によつ て測定した.

母血清中ならびに胎仔 carcass の homogenate 中の hot FFA 量は, それぞれの $1 \mathrm{ml}$ から前述の抽出溶 液 $5 \mathrm{ml}$ を用いて FFA を抽出した後, さらにヘプタンを加え 5 分後にヘプタン抽出層 $1 \mathrm{ml}$ を Bray solution に溶解し， Packard トリカルブ 3320 型の液体シンチレーションカウンターにより $\mathrm{C}_{14}$ の放射能を測定した.

母体子宮周囲脂肪組織ならびに胎仔 carcass の hot TG 量については, それぞれ細断した後, 組織重量 の約20倍量の Bloor 抽出液を加え, Potter-Elvhjem 型 homogenizer で homogenate するととによつて TG を抽出し, 抽出した粗 TG 分画は, 石油エーテルを基質とした展開液（石油エーテル 90 : エーテル 10 ：酢酸 1 ）を用いシリカゲル薄層クロマト法によつて約 12 時間展開分離したあと，TGにあたる部分を薄 層より削りとり，それをトルエンベース溶解液に溶解し，Packard トリカルブ 3320 型の液体シンチレーシ ョンカウンターにより $\mathrm{C}_{14}$ の放射能を測定した。

b. S.D. 系妊娠ラットに oleic acid-1-G $\mathrm{C}_{14}$ を使用した場合

12時間絶食された妊娠 $L_{16}$ の S.D. 系ラット（体重 $350 \mathrm{gr}$ 前後）を使用し, Wistar 系ラットの場合と全 く同様の実験操作を行なつた.

c. Wistar 系妊娠ラットに $\mathrm{C}_{14}$-D-glucose (U) を使用した場合

日本放射性同位元素協会頒布の Lot. No. 137-29 の $\mathrm{G}_{14}$-D-glucose $17 \mu \mathrm{Ci}$ を, 滅菌生理食塩水けんだく 混合溶液 (glucose $0.1 \%$, BSA $0.1 \%$, cold oleic acid $0.2 \%$ ) $2 \mathrm{ml}$ で emulsion とし, あらかじめ妊娠 $\mathrm{L}_{16}$ より 1 匹当り $\mathrm{h} \Gamma \mathrm{L} 100 \mu \mathrm{g}$ を腹腔内へ連続投与した妊娠 $\mathrm{L}_{16}$ の Wistar 系ラット尾静脈に投与した, 10時間 後にと殺し, 母血清中の glucose 量を前述の如く Hoffman と Auto Analyzer Technicon Laboratory 法 で測定し，またその一部の血清 $1 \mathrm{ml}$ は, Bray solution に溶解して $\mathrm{C}_{14}$-D-glucose の放射能を測定した.

一方胎仔については, 肝臟をとり出し, トーションバランスによりその重量を科量したあと, 前述の如 くGood の方法で glycogen を抽出し, $2 \mathrm{~N} \mathrm{H}_{2} \mathrm{SO}_{4}$ で還元 glucose としたあと, Hoffman と Auto Analyzer Technicon Laboratory 法で cold glucose を測定し，その一部は Bray solution に溶解した後, 液体シンチレーションカウンターにより $\mathrm{C}_{14}$-D-glucose (U) の放射能を測定した.

\section{B. 実験成績}

\section{1. 胎仔の発育と胎仔および妊娠ラット血中の glucose, FFA，TG ならびに T-N 量におよぼす hPL の影響}

$\mathrm{L}_{3}$ から $\mathrm{L}_{21}$ までと $\mathrm{L}_{10}$ から $\mathrm{L}_{21}$ までの期間に, hPL を 1 日当りそれぞれ $15 \mu \mathrm{g}, 50 \mu \mathrm{g}$ および $100 \mu \mathrm{g}$ を連日投与した各妊娠ラット群から， $\mathrm{L}_{21}$ に直接開腹によつて得た胎仔の体重, 身長, 脛骨長ならびに心臓, 朋臟および腎臓などの各蔵器の重量を Table 1 亿示す.

コントロール 1 群胎仔の体重 $3.4 \mathrm{gr}$ に比して， G-2 群胎仔のそれは $4.5 \mathrm{gr}$.であり他の hPL 投与群の胎 仔体重は増加を示しているが，特にC-2 群についてはコントロール 1 群のそれに対して $30 \%$ 上の体重増 
Table 1. Effects of hPL on the development of the foetus. (in Wistar strain)

\begin{tabular}{|c|c|c|c|c|c|c|c|}
\hline groups & $\begin{array}{c}\text { control } \\
1 \\
\end{array}$ & $\begin{array}{c}\text { control } \\
2 \\
\end{array}$ & $A-1$ & $A-2$ & B -1 & B -2 & $\mathrm{G}-2$ \\
\hline treated period & $\mathrm{L}_{3}-\mathrm{L}_{21}$ & $\begin{array}{c}\text { just } \\
\text { delivered }\end{array}$ & $\mathrm{L}_{3}-\mathrm{L}_{21}$ & $\mathrm{~L}_{10}-\mathrm{L}_{21}$ & $\mathrm{~L}_{3}-\mathrm{L}_{21}$ & $\mathrm{~L}_{10}-\mathrm{L}_{21}$ & $\mathrm{~L}_{10}-\mathrm{L}_{21}$ \\
\hline daily dose & & & \multicolumn{2}{|c|}{${ }^{*} \mathrm{hPL} 15 \mu \mathrm{g}$} & \multicolumn{2}{|c|}{ hPL $50 \mu \mathrm{g}$} & hPL $100 \mu \mathrm{g}$ \\
\hline body weight $\mathrm{g}$ & $\begin{array}{r}3.4 \pm \\
0.2\end{array}$ & $\begin{array}{r}4.7 \pm \\
0.2\end{array}$ & $\begin{array}{c}4.2 \pm \\
0.5\end{array}$ & $\begin{array}{c}4.5 \pm \\
0.1\end{array}$ & $\begin{array}{c}4.3 \pm \\
0.1\end{array}$ & $\begin{array}{r}4.4 \pm \\
0.1\end{array}$ & $\begin{array}{c}4.5 \pm \\
0.1\end{array}$ \\
\hline body length $\mathrm{cm}$ & $\begin{array}{c}3.4 \pm \\
0.0\end{array}$ & $\begin{array}{c}3.8 \pm \\
0.2\end{array}$ & $\begin{array}{c}3.8 \pm \\
0.1\end{array}$ & $\begin{array}{c}3.8 \pm \\
0.1\end{array}$ & $\begin{array}{c}3.7 \pm \\
0.0\end{array}$ & $\begin{array}{c}3.8 \pm \\
0.0\end{array}$ & $\begin{array}{c}3.8 \pm \\
0.0\end{array}$ \\
\hline tibial length $\mathrm{mm}$ & $\begin{array}{r}8.0 \pm \\
0.0\end{array}$ & $\begin{array}{r}9.0 \pm \\
0.1 \\
\end{array}$ & $\begin{array}{r}8.7 \pm \\
0.3 \\
\end{array}$ & $\begin{array}{r}8.8 \pm \\
0.1 \\
\end{array}$ & $\begin{array}{r}8.9 \pm \\
0.0\end{array}$ & $\begin{array}{r}9.0 \pm \\
0.0\end{array}$ & $\begin{array}{r}9.3 \pm \\
0.0\end{array}$ \\
\hline heart weight $\mathrm{mg}$ & $\begin{array}{r}20.0 \pm \\
0.8\end{array}$ & $\begin{array}{r}26.4 \pm \\
1.6\end{array}$ & $\begin{array}{r}33.2 \pm \\
3.8\end{array}$ & $\begin{array}{r}28.0 \pm \\
1.0\end{array}$ & $\begin{array}{r}24.4 \pm \\
0.5\end{array}$ & $\begin{array}{c}28.6 \pm \\
1.2\end{array}$ & $\begin{array}{c}29.6 \pm \\
0.4\end{array}$ \\
\hline liver weight $\mathrm{mg}$ & $\begin{array}{r}206.2 \pm \\
9.7\end{array}$ & $\begin{array}{r}237.9 \pm \\
12.6\end{array}$ & $\begin{array}{r}254.7 \pm \\
69.7\end{array}$ & $\begin{array}{r}308.7 \pm \\
8.6\end{array}$ & $\begin{array}{r}306.3 \pm \\
9.2\end{array}$ & $\begin{array}{r}328.7 \pm \\
14.3\end{array}$ & $\begin{array}{r}350.5 \pm \\
12.3\end{array}$ \\
\hline kidney weight $\mathrm{mg}$ & $\begin{array}{r}25.7 \pm \\
1.3 \\
\end{array}$ & $\begin{array}{r}44.8 \pm \\
5.6 \\
\end{array}$ & $\begin{array}{r}40.3 \pm \\
7.7 \\
\end{array}$ & $\begin{array}{r}.45 .1 \pm \\
4.3 \\
\end{array}$ & $\begin{array}{c}35.3 \pm \\
1.4\end{array}$ & $\begin{array}{c}36.7 \pm \\
1.2 \\
\end{array}$ & $\begin{array}{r}34.9 \pm \\
0.8\end{array}$ \\
\hline placenta mg & $\begin{array}{r}420.2 \pm \\
16.8 \\
\end{array}$ & & $\begin{array}{r}470.3 \pm \\
30.3 \\
\end{array}$ & $\begin{array}{c}465.7 \pm \\
28.6 \\
\end{array}$ & $\begin{array}{r}456.2 \pm \\
19.8\end{array}$ & $\begin{array}{c}461.1 \pm \\
11.7\end{array}$ & $\begin{array}{r}480.0 \pm \\
12.5 \\
\end{array}$ \\
\hline
\end{tabular}

*HPL was injected into pregnant rats during $\mathrm{L}_{3}-\mathrm{L}_{21}$ or $\mathrm{L}_{10}-\mathrm{L}_{21}$. Pregnant rats were sacrificed on $L_{21}$ and foetus were weighed out immediately.

Table 2. Ratio of dry weight to wet weight of various organs of the foetus. (in Wistar strain)

\begin{tabular}{l|c|c|c}
\hline \hline organs & control 1 & $\begin{array}{c}\text { B-2 } \\
\text { hPL *50g }\end{array}$ & $\begin{array}{c}\text { C-2 } \\
\text { hPL } 100 \mathrm{~g} / \text { day }\end{array}$ \\
\hline wet weight of liver/body weight & $6.5(\%)$ & $7.4(\%)$ & $7.2(\%)$ \\
dry weight of liver/wet weight of liver & 21.4 & 23.2 & 23.0 \\
wet weight of heart/body weight & 0.5 & 0.5 & 0.5 \\
dry weight of heart/wet weight of heart & 15.0 & 19.0 & 20.0 \\
wet weight of kidney/body weight & 0.7 & 0.3 & 0.7 \\
dry weight of kidney/wet weight of kidney & 16.1 & 15.0 & 14.3 \\
\hline
\end{tabular}

*HPL was administered into pregnant rats $\left(50 \mu \mathrm{g}\right.$ per day or $100 \mu \mathrm{g}$ per day during $\left.\mathrm{L}_{10}-\mathrm{L}_{21}\right)$.

加を認めた。

また hPL 投与の時期については， A 群， B 群ともに $\mathrm{L}_{10}$ から $\mathrm{L}_{21}$ まで $\mathrm{hPL}$ を投与した方が体重増加 は大であつた.

hPL 投与群胎仔の各藏器重量ならびに身長と脛骨長はいずれの群もコントロール 1 群に比し増大してい るが特に G-2 群については肝藏で 1.7 倍，心臟で

1.5 倍，腎藏で 1.4 倍と増加しており，かつ身長は

1.1 倍, 脛骨長は 1.2 倍であつた。

Table 2 は各臟器の湿重量に対する乾燥重量の割 合と胎仔の体重に対する各臟器重量の割合を示して いる.

hPL 母体投与群胎仔の体重に対する各藏器重量 の割合いは, B-2 群, $\mathrm{C}-2$ 群ともにコントロール 1 群に比し肝臟, 心臓では大となつているが, 腎臓 ではB－2 群に増加を認めたのみであつた。

Fig. 1 は胎仔の体重に対する各臟器重量の割合を
Fig. 1. Ratio of wet weight of organ to body weight of the foetus. (in Wistar Strain)

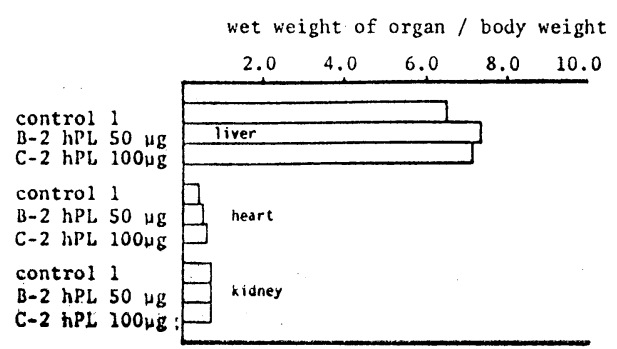


四示した。

Table 3 と Fig. 2 は, 胎仔各臟器の glycogen 含有量をしめす。

hPL 母体投与群胎仔の肝 glycogen 量ならびに心 glycogen 量はコントロール1群に比し増量を示し, 特にC-2 群においてはそれぞれコントロール1群の 2 倍, 1.7 倍と增加しているが, 腎臓では glucogen 量 の增加を慧めなかつた。

Table 4 と Fig. 3 は胎仔 carcass の glucose, FFA, TG ならびに T-N 量を示めす.

hPL 投与群胎仔 carcass の glucose 量は, コントロール1群胎仔のそれに比しB-2 群での 1.1 倍, C2 群で 1.1 倍, FFA 量はB-2 群でコントロール1群の 1.2 倍, G-2 群で 1.3 倍, TG 量はB-2 群でコン トロール 1 群の 1.5 倍, C-2 群で 1.9 倍, T-N 量はB-2 群で 1.4 倍, C-2 群で 1.7 倍でいずれも增加した.

また hPL の投与量の差によるてれらの物質の量的な比較では，一日当り $50 \mu \mathrm{g}$ 投与よりも $100 \mu \mathrm{g}$ 投与 群の方が glucose, FFA, TG ならびに T-N 量增加の割合いが大であつた。

Table 3. Total glycogen in liver, heart and kidney of the foetus. (in Wistar Strain)

\begin{tabular}{c|r|r|c}
\hline \hline organs & control 1 & hPL $* 50 \mu$ g-day & hPL $\begin{array}{c}\text { C-2 } \\
\text { o-2 } \mu \text { g/day }\end{array}$ \\
\hline \hline liver $\mathrm{mg} / \mathrm{g}$ & $28.7 \pm 2.4$ & $58.3 \pm 6.8$ & $54.7 \pm 5.6$ \\
heart $\mathrm{mg} / \mathrm{g}$ & $10.8 \pm 0.6$ & $18.7 \pm 2.3$ & $17.33 \pm 3.1$ \\
kidney $\mathrm{mg} / \mathrm{g}$ & $2.3 \pm 0.2$ & $2.2 \pm 0.3$ & $2.32 \pm 0.18$ \\
\hline
\end{tabular}

*HPL was administered into pregnant rats $\left(50 \mu \mathrm{g}\right.$ or $100 \mu \mathrm{g}$ per day during $\left.\mathrm{L}_{10}-\mathrm{L}_{21}\right)$.

Fig. 2. Total glycogen in liver, heart and kidney of rat foetus. (in Wistar strain)

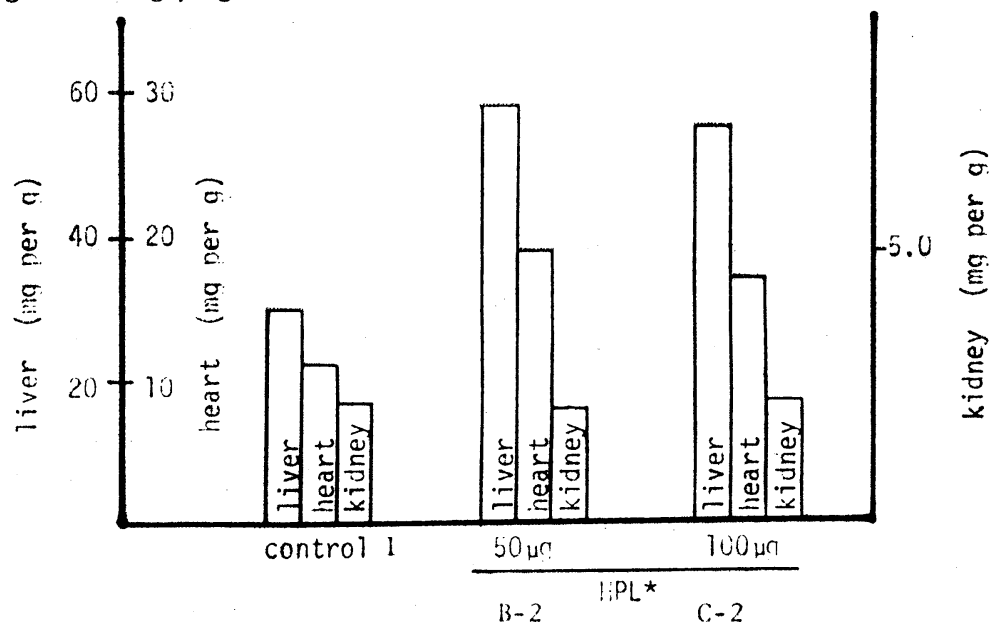

*HPL was injected into pregnant rats $\left(50 \mu \mathrm{g}\right.$ or $100 \mu \mathrm{g}$ per day during $\left.\mathrm{L}_{10}-\mathrm{L}_{21}\right)$.

Table 4. Glucose, FFA, TG and $\mathrm{T}-\mathrm{N}$ in the carcass of the foetus on $\mathrm{L}_{31}$. (in Wistar strain)

\begin{tabular}{c|c|c|c|c|c}
\hline groups & hPL & glucose mg/g & FFA meg/g & TG mg/g & T-N mg/g \\
\hline \hline eontrol 1 & - & $8.36 \pm 0.6$ & $3.37 \pm 0.4$ & $1.36 \pm 0.3$ & $97.6 \pm 4.3$ \\
B-2 & $50 \mu \mathrm{g} /$ day* & $9.02 \pm 0.4$ & $4.01 \pm 0.2$ & $2.05 \pm 0.2$ & $134.2 \pm 5.6$ \\
C-2 & $100 \mu \mathrm{g} /$ day* & $9.12 \pm 0.2$ & $4.39 \pm 0.5$ & $2.55 \pm 0.4$ & $165.0 \pm 10.1$ \\
\hline
\end{tabular}

*HPL was injected into pregnant rats during $\mathrm{L}_{10}-\mathrm{L}_{21}$. 
Fig. 3. Total nitrogen, triglyceride and glucose in the carcass of the foetus on $\mathrm{L}_{21}$. (in Wistar strain)

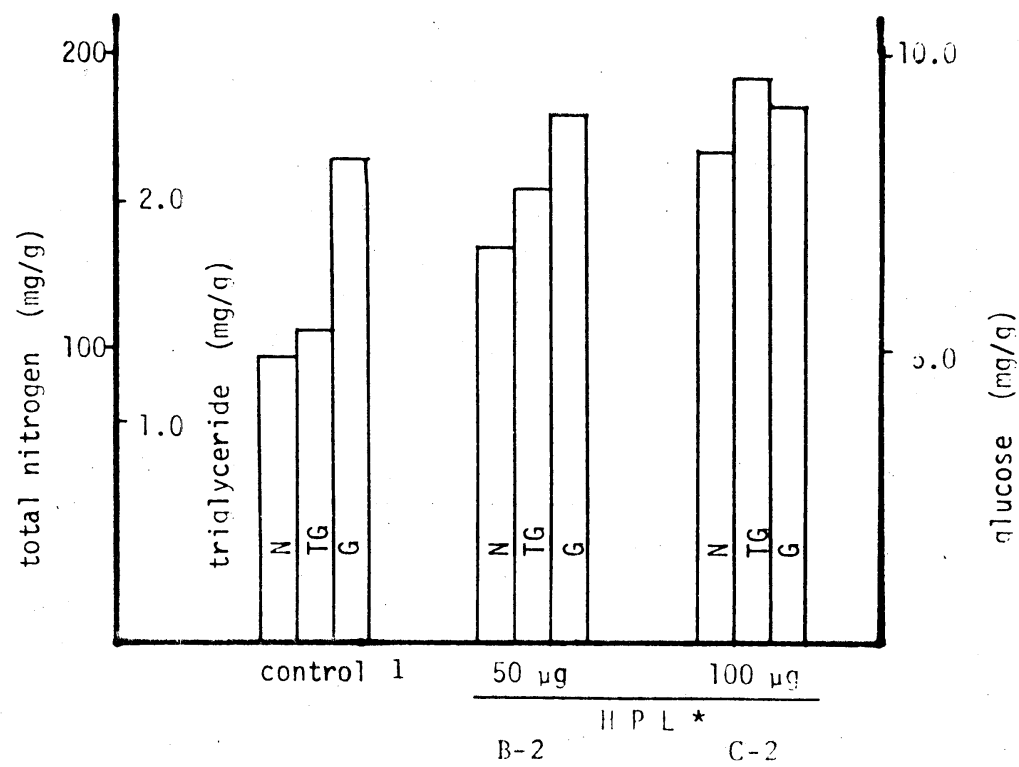

*HPL was injected into pregnant rats during $\mathrm{L}_{10}-\mathrm{L}_{21}$.

一方， $\mathrm{L}_{10}$ から $\mathrm{L}_{21}$ まで $\mathrm{hPL}$ を一日当り $50 \mu \mathrm{g}$ あるいは $100 \mu \mathrm{g}$ 連続投与をうけた弤娠ラット血清中の glucose, FFA, TG ならびに T-N 量を Table 5 と Fig. 4 亿示めす.

妊娠ラット血清中の glucose 量は, B-2 群ではコントロール 1 群の 1.6 倍, C-2 群では 1.7 倍であり, FFA 量はB-2 群で 1.7 倍, G-2 群で 1.8 倍, TG 量は B-2 群で 1.1 倍, G-2 群で 1.3 倍, T-N 量は B-2で 1.1 倍, G-2 群で 1.2 倍であつた.

\section{2.母体および胎仔の glucose, FFA ならびに TG 量の変化に及ぼす hPL の影響}

i. Wistar 系妊娠ラットに oleic acid-1-C $\mathrm{C}_{14}$ を使用した場合

$\mathrm{HPL}$ 投与群および非投与群母血清中の $\mathrm{C}_{14}$-FFA と cold FFA 量, ならびに脂肪組織中の $\mathrm{C}_{14}$ - $\mathrm{TG}$ 量を Fig. 5 にしめす.

コントロール 1 は oleic acid-1-G $\mathrm{G}_{14}$ 投与後 6 時間目の, コントロール 2 は投与後10時間目の成績をしめすが, hPL 投与群の成績は， oleic acid-1-G $\mathrm{C}_{14}$ 投与 6 時間目に更に hPL を投与し，その後 4 時間目のものである.

母血清中の $\mathrm{C}_{14}$-FFA と cold FFA ならびに脂肪組織の $\mathrm{G}_{14}$ - $\mathrm{TG}$ 量は, コントロールに比べコントロール 2 ではいずれも軽度に上舁しているが，hPL 投与群ではコントロール 2 に比べて血清中の $\mathrm{C}_{14}-\mathrm{FFA}$ 量は約 7.4 倍, cold-FFA 量は約 2 倍, また脂肪組織中の $\mathrm{G}_{14}-\mathrm{TG}$ 量は約 10 倍と著増している.

Table 5. Glucose, FFA, TG and T-N in the serum of the pregnant rat on $\mathrm{L}_{21}$. (in Wistar strain)

\begin{tabular}{c|c|r|r|r|c}
\hline groups & hPL & glucose mg/dl & FFA $\mu$ eg/dl & TG mg/dl & T-N mg/dl \\
\hline \hline control 1 & - & $68.2 \pm 3.2$ & $78.3 \pm 8.0$ & $173.5 \pm 10.3$ & $45.6 \pm 2.1$ \\
B-2 & $50 \mu \mathrm{g} /$ day* & $110.2 \pm 5.8$ & $135.2 \pm 9.5$ & $190.6 \pm 5.8$ & $51.1 \pm 1.8$ \\
C-2 & $100 \mu \mathrm{g} /$ day* & $116.8 \pm 6.2$ & $141.8 \pm 6.3$ & $230.8 \pm 8.8$ & $52.8 \pm 1.5$ \\
\hline
\end{tabular}

*Pregnant rats were injected with hPL $\left(50 \mu \mathrm{g}\right.$ per day or $100 \mu \mathrm{g}$ per day during $\left.\mathrm{L}_{10}-\mathrm{L}_{21}\right)$. 
Fig. 4. Triglyceride, total $\mathrm{N}$ and glucose in the serum of the pregnant rat on $\mathrm{L}_{21}$. (in Wistar strain)

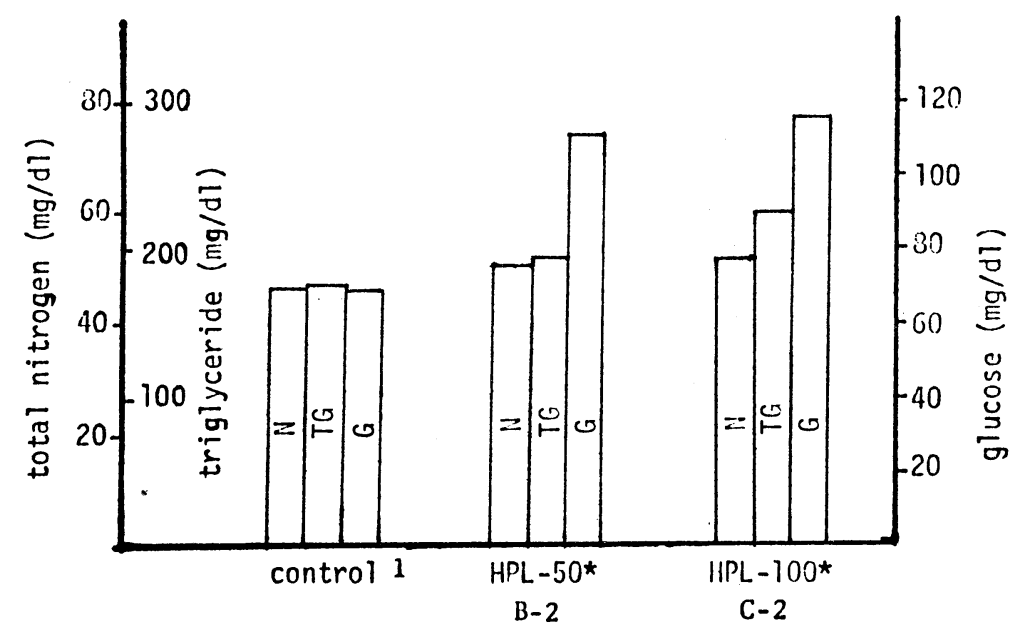

*HPL $(50 \mu \mathrm{g}$ or $100 \mu \mathrm{g}$ per day) was injected into the pregnant rats during $\mathrm{L}_{10}$ to $\mathrm{L}_{21}$.

Fig. 5. Effect of the administration of hPL on concentrations of $\mathrm{G}_{14}$-FFA, cold FFA in the serum and $\mathrm{C}_{14}$-TG in the fat pad. (Pregnant rats in Wistar strain)

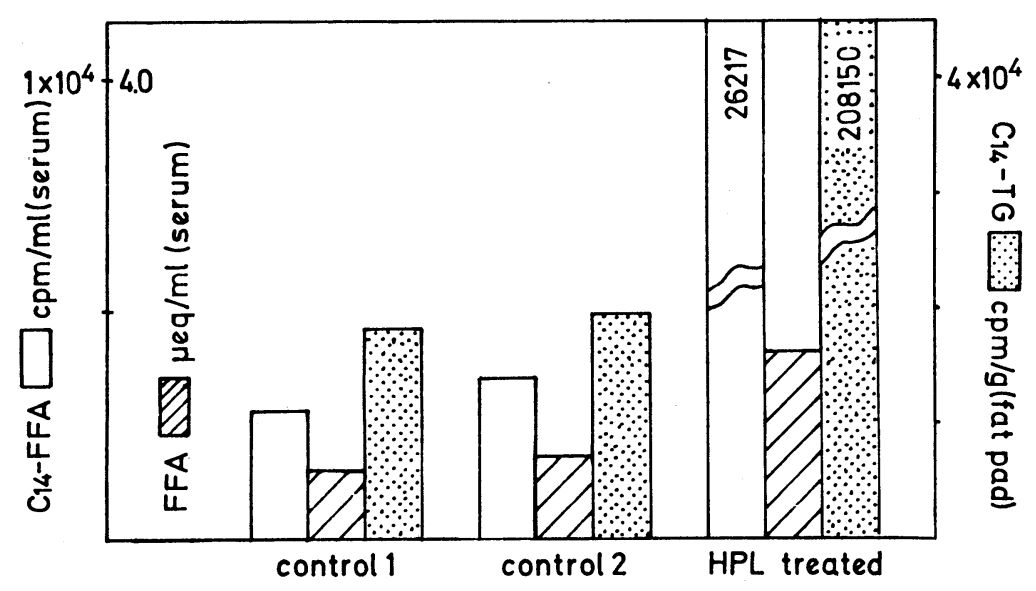

またての際の母血清中の cold glucose, FFA ならびに TG 量は Fig. 6 にしめす. コントロール 2 では コントロール1のそれと比べ, FFA と TG 量は増加しているものの, glucose 量はやや減少している. ま た hPL 投与群ではコントロール 2 に比して glucose 量はその 1.4 倍, FFA 量は 2 倍, TG 量は 5.5 倍と いずれも著増していた。

一方, 胎仔 carcass の $\mathrm{C}_{14}$-FFA, cold FFA, $\mathrm{C}_{14}$-TG 量は Fig. 7 に示めす. コントロール 2 ではコント ロール 1 に比べいずれも軽度の増加傾向をしめしているが，hPL 投与群仔胎では，コントロール 2 に比し て， $\mathrm{G}_{14}$-FFA はその 3.9 倍, cold FFA は 2 倍, $\mathrm{G}_{14}$-TG は 4.3 倍といずれも著増した。

ii. S.D. 系妊娠ラットに oleic acid-1- $\mathrm{C}_{14}$ を使用した場合

HPL 投与群および非投与群母血清中の $\mathrm{C}_{14}$-FFA と cold FFA 量ならびに脂肪組織の $\mathrm{C}_{14}$ - TG 量を Fig. 8 
Fig. 6. Effect of the administration of hPL on concentrations of FFA, TG and glucose in the serum. (Pregnant rats in Wistar strain)

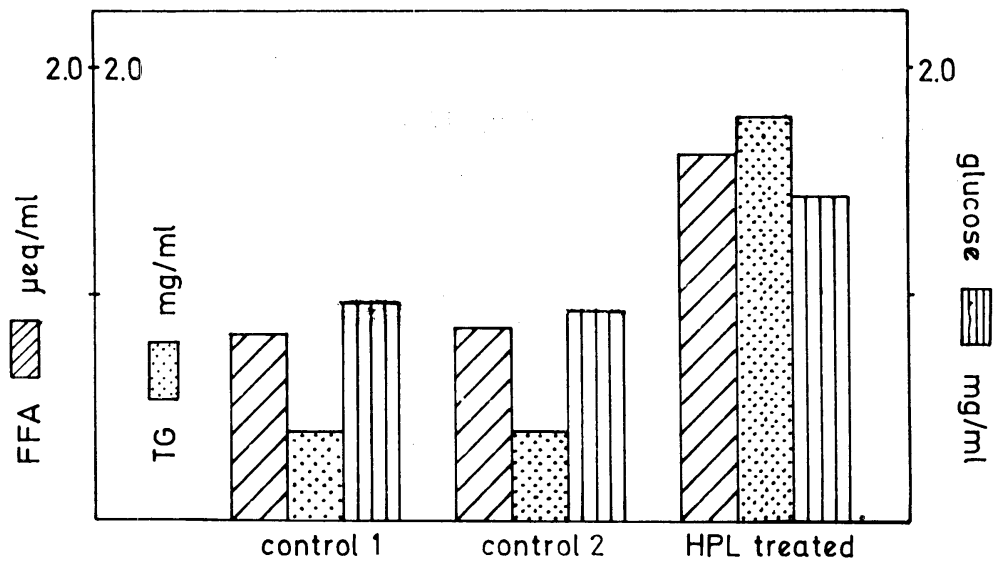

Fig. 7. Effect of the administration of $\mathrm{hPL}$ on $\mathrm{C}_{14}$-FFA, cold FFA and $\mathrm{C}_{14}-\mathrm{TG}$ contents of the foetus. (Pregnant rats in Wistar strain)

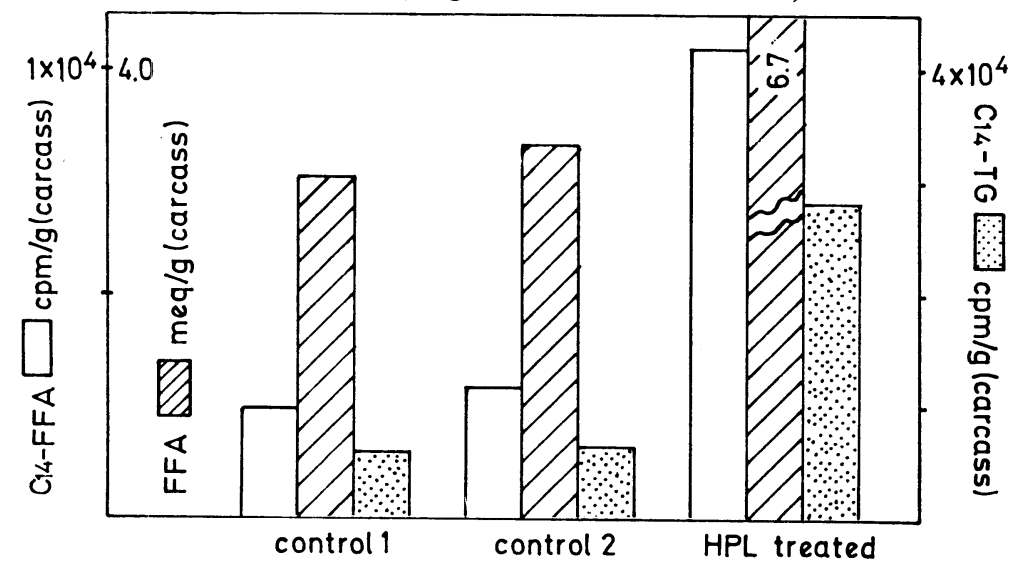

Fig. 8. Effect of the administration of hPL on concentrations of $\mathrm{G}_{14}$-FFA, cold FFA in the serum and $\mathrm{C}_{14}$-TG in the fat pad.(Pregnant rats in S.D. strain)

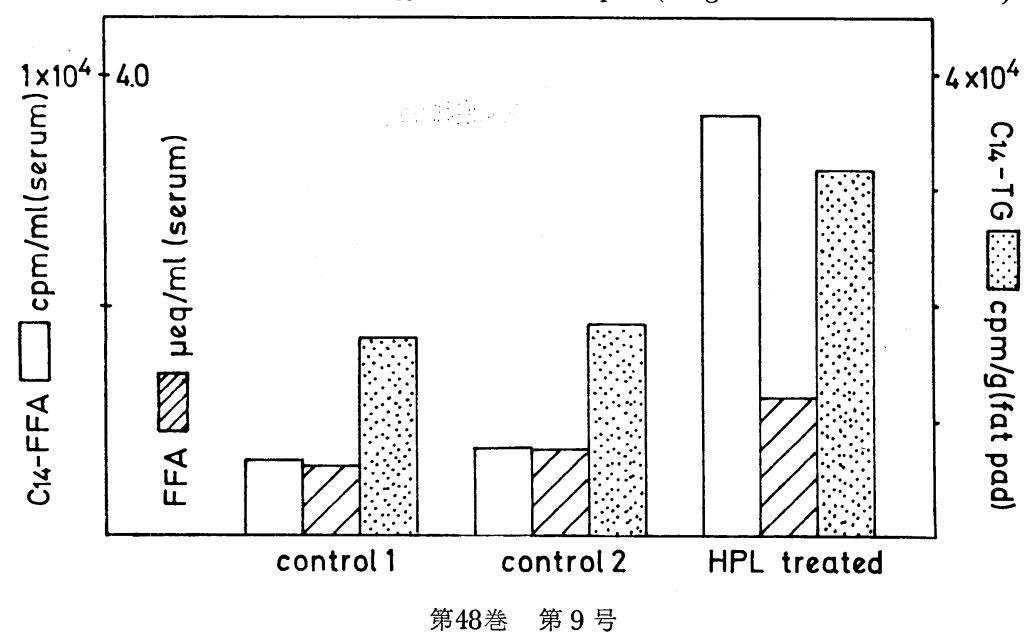


にしめす.

HPL 投与群では, コントロール 2 亿比して血清中の $\mathrm{C}_{14}$-FFA 量は4.7倍, cold FFA 量は1.7倍, 脂肪組 織の $\mathrm{C}_{14}$ - TG 量は 1.8 倍と増加している。しかし前述の Wistar 系ラットの場合と比較するとその量的增加 は高度ではない。

母血清中の cold glccose, FFA と TG 量を Fig. 9 そしめす.

コントロール1亿比べてコントロール 2 の FFA 量と TG 量はわずかに増加しているが, glucose 量は むしろやや減少している。一方, hPL 投与群ではコントロール 2 に比して glucose 量は 1.3 倍, FFA 量 は1.5 倍, TG 量は 1.5 倍でいずれも増加した.

胎仔 carcass の $\mathrm{C}_{14}$-FFA, cold FFA, $\mathrm{C}_{14}$-TG 量を Fig. 10 にしめす.

HPL 投与群胎仔では, コントロール 2 そ比べ $\mathrm{C}_{14}$ - $\mathrm{FFA}$ 量は 2.8 倍, cold FFA 量は 1.9 倍, $\mathrm{C}_{14}$ - $\mathrm{TG}$ 量 は 2.9 倍となりいずれも増加した。

\section{iii. Wistar 系妊娠ラットに $\mathrm{C}_{14}$-D-glucose を使用した場合}

Fig. 9. Effect of the administration of hPL on concentrations of FFA, TG and glucose in the serum. (Pregnant rats in S.D. strain)

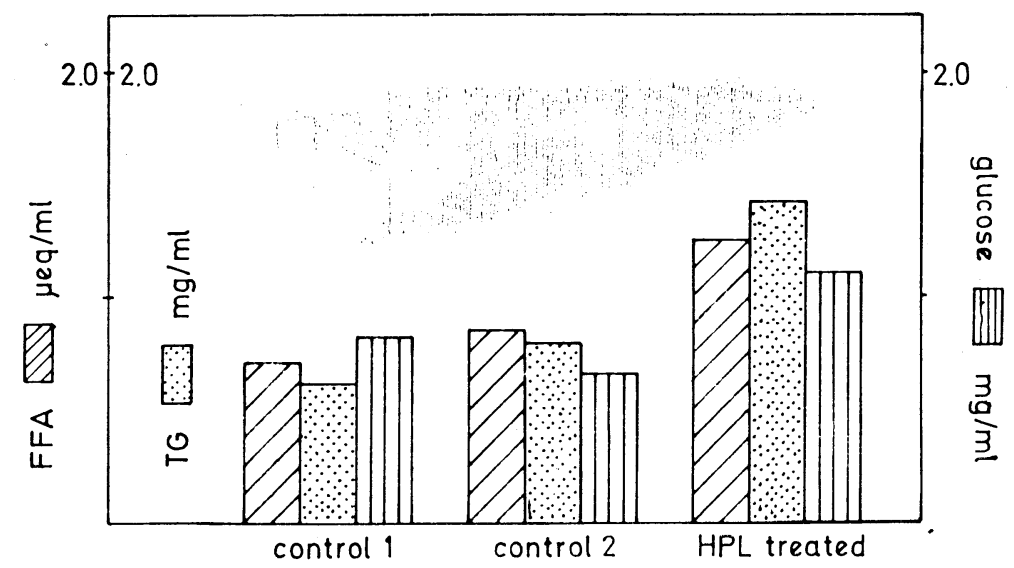

Fig. 10. Effect of the administration of hPL on $\mathrm{C}_{14}$-FFA, cold FFA and $\mathrm{C}_{14}$-TG contents of the foetus. (Pregnant rats in S.D. strain)

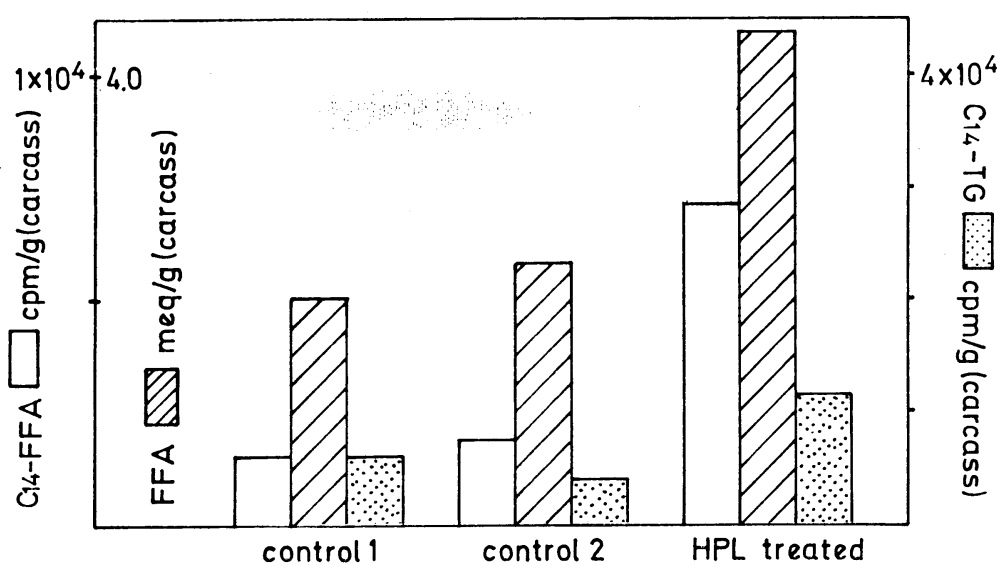

第 48 巻 第 9 号 
母血清中の glucose および $\mathrm{C}_{14}$-D-glucose の量を Fig. 11 亿示す.

HPL 非投与群に比して hPL 投与群母血清の cold glucose 量は 1.5 倍と増加しているが, $\mathrm{C}_{14}$-D-glucose 量は非投与群のそれよりも $30 \%$ 減少した。

一方, 胎仔肝臓中の cold glucose および $\mathrm{C}_{14}$-D-glucose の量は Fig. 12 の如くで, 非投与群に比し, 投 与群胎仔の glucose 量は 1.2 倍, $\mathrm{C}_{14}$-D-glucose 量は 1.4 倍と増加した.

Fig. 11. Effect of the administration of hPL on contents of glucose and D-glucose$\mathrm{C}_{14}(\mathrm{U})$ in the serum. (Pregnant rats in Wistar strain)

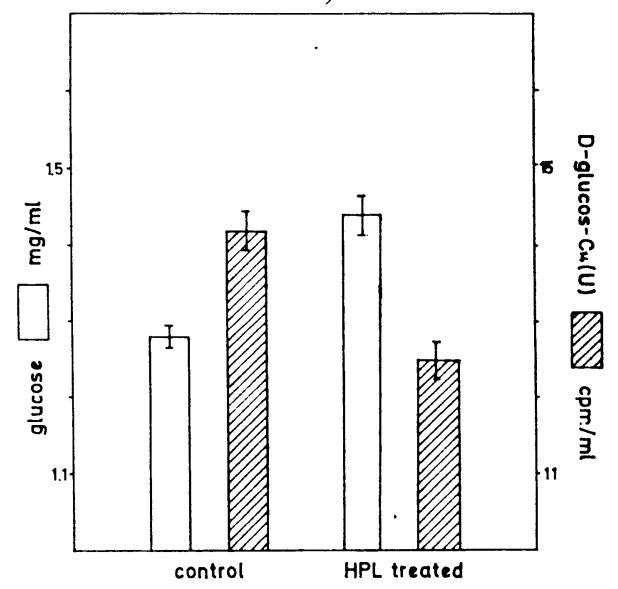

Fig. 12. Effect of the administration of hPL on contents of glucose and D-glucose$\mathrm{G}_{14}(\mathrm{U})$ in foetal liver. (Pregnant rats in Wistar strain)

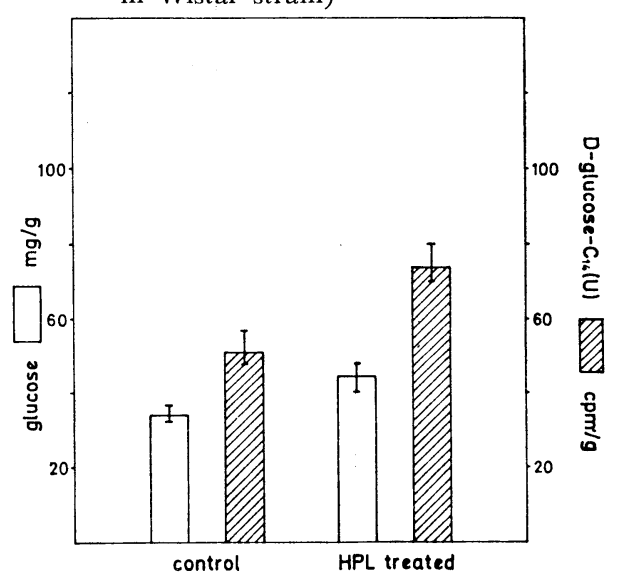

\section{C. 小括之考按}

HPL のもつ固有の生物学的性格の一つである lipolytic action が妊娠時, 胎览の発育に対してどのよう な影響をしめすか，つまり児の発育が hPL の投与によつて妊娠個体で惹起された glucose fatty acid cycle の変化にどのように影響されるかを知らうとして，著者はまず Wistar 系妊娠ラットに妊娠初期あるいは中 期から末期まで hPL を連続的に投与し, 妊娠末期に開腹によつて胎仔をとり出し，その時期の胎仔の発育 の状態や, 胎仔 carcass の glucose, FFA, TG ならびに T-N 量と, 母血清中の glucose, FFA, TG なら びに T-N 量を hPL 非投与群母体および胎仔のそれらと比較することによつて検討した。

これらの成績は先述した如くであつて， $\mathrm{L}_{10}$ より $\mathrm{L}_{21}$ まで一日当り $100 \mu \mathrm{g}$ のPL を連続投与した妊娠 ラットより得られた胎仔の体重は, hPL 母体非投与群胎仔のそれより約 $25 \%$ 増加し, 各㵴器の湿重量なら びに乾燥重量も同様に投与群において有意に増加した。

また, てれらの臟器の glycogen 含有量は, 非投与群胎仔のそれよりも約 2 倍の増加をしめし, かつ, 胎 仔 carcass の glucose, FFA, TG ならびに T-N 量も有意に増加していたが, 一方, 母体においても血清中 の glucose, FFA, TG ならびに T-N 量はすべて非投与群のそれらに比して著増しているという興味ある 成績が得られた。

つまり, 妊娠ラットに hPL を連続投与するととによつて, 胎児の発育に必要であると考えられる母血清 中の glucose, FFA, TG, ならびに T-N 量が先ず増加し, かつ, ての増加傾向と胎仔の発育は, hPL の 投与量と投与時期に左右されるようであつて，hPL の量は一日当り $50 \mu \mathrm{g}$ よりは $100 \mu \mathrm{g}$ が，弤娠初期から の投与よりは妊娠中期からの投与の方がてのような変化をおてすためにはより効果的であつた.

次に, feto placental-maternal system そおける glucose fatty acid cycle の動きを検討する目的から, 標識 oleic acid であらかじめ母体の脂肪組織を標識した後に hPL を母体に投与し, その後の母体脂肪組織 内 $\mathrm{C}_{14}$-TG 量, 母血清中の $\mathrm{C}_{14}$-FFA 量の推移と, さらに cold FFA, cold TG, cold glucose 量ならびに 
胎仔 carcass $の \mathrm{C}_{14}$-FFA と $\mathrm{G}_{14}$ - $\mathrm{TG}$ ならびに cold FFA 量を測定した.

その結果は, hPL 投与群妊妮ラットにおいて脂肪組織におけるきわめて有意な $\mathrm{C}_{14}$-TG の蓄積と, 血清 中での $\mathrm{C}_{14} \mathrm{FFA}$ 量および cold FFA 量の增加力認められ, 一方胎仔では, 特に hPL 母体投与群胎仔にお いて $\mathrm{C}_{14}$ - FFA, cold FFA ならびに $\mathrm{C}_{14}$-TG 量の増加が認められた。 また hPL 投与によつて妊娠ラット血 清中の cold FFA, TG, glucose 量は著明に增加していた.

つまり, 被検動物に Wistar 系妊娠ラットあるいは S.D. 系妊娠ラットを使用しても, あらかじめ脂肪組 織を標識しておいたてれらの妊娠ラットに hPL を投与すると, 血清中の $\mathrm{C}_{14}$-FFA の增加が認められると

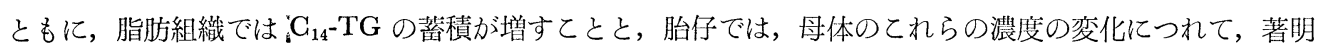
な $\mathrm{C}_{14}$-FFA， $\mathrm{C}_{14}$-TG, cold FFA 量の増加が認められた。 ただし，使用動物の種類によつて，hPL のての ような作用に量的差が認められたととは興味ある成績であるが，乙の原因は，おそらく使用した Wistar 系 と S.D. 系ラットの H.S.L. や Lipoprotein Lipase (L.P.L.) 活性を考慮した年令的な差，また体重あたり の投与量の差によるものと思われる.

また, Wistar 系妊娠ラットに標識 glucose を投与した後 hPL を投与し, 母血清中の $\mathrm{C}_{14}$-glucose と cold glucose の量的な変化ならびに胎仔肝㵴での両者の量的な割合いを検討すると, hPL 投与によつて, 母血清 中の cold glucose 量の増加と, 逆に $\mathrm{C}_{14}$-glucose 量の減少が認められ, 一方胎仔肝蔵では cold glucose な らびに $\mathrm{C}_{14}$-glucose 量の著增が確認できた。

以上の標識脂肪組織を使用した実験ならびに本実験の成績をまとめて考察すると，hPL の母体投与によ つて, 母体では脂肪分解, 次いで合成が共に交進し, 母体血中に避離された FFA はおちらく胎巟にも移行 するであろうが多くは母体で利用される可能性が強く, 母体の glucose fatty acid cycle は, fatty acid が 優位となる結果, glucose は当然果体血中に増量し, かつ, 胎児の発育に最も重要な因子であるての glucose は, 母体血中の濃度に従つて胎児へ移行するものと考学られる. 従つて, 妊娠ラトッに hPL を連続投与し た結果，その胎児の発育が30\%以上にも六進するという原因は，恐らくは妊娠個体つまり母体側における hPL の lipolytic な作用に起因するものと推察される.

\section{III. 胎仔に対する hPL の直接作用}

一胎仔への直接投与実験一

\section{A. 実験材料と方法}

\section{1. 実験材料}

実験材料には II-1-i, II-1-ii-a 亿記載した hPL と被験動物を利用した。

また胎仔の L.P.L. ならびに H.S.L. 活性の測定には， $\mathrm{L}_{21} の$ Wistar 系妊娠ラットの胎仔，生後 1 日目 と10日目の新生仔と 3 ケ月後の Wistar 系ラットならびに老鼠を使用した.

\section{2. 実験方法}

i. HPL を胎仔に直接投与した際の妊娠ラットならびに胎仔における glucose, FFA, TG および T-N 量の変化

妊娠 $\mathrm{L}_{21}$ Wistar 系ラットをエーテル麻酔下で開腹し, 一側子宮角内の胎仔腹腔内へ一匹当り hPL $50 \mu \mathrm{g}$ をそれぞれ投与した後, 直ちに開腹し, hPL 投与 4 時間目に子宮周囲血管より採血し, その血清より glucose そ FFA 量を, 一方胎仔では hPL を投与した胎仔と非投与他側子宮角内胎仔についてそれぞれ先述の如く 生理食塩水 $2 \mathrm{ml}$ で homogenate を作成し, てれらの胎仔 homogenate について glucose, FFA, TG なら びに T-N 量を II-2-i に記載した方法で測定した。

\section{ii. 胎仔 carcass ならびに新生仔の Lipase 活性の検討}

L.P.L. の測定は，中田氏法5) (1969)，つまりそれぞれの胎仔 carcass をトーションバランスにより正確に 秤量したあと，約20倍量のドラィアイス冷却アセトンを加え，佐久間式 homoblender により15分間粉砕乳 化し，直ちに東洋ろ紙 No. 50 をひいた Büchner ろ斗にて吸引ろ過し，残渣が完全に乾燥するまで数回アセ 
トンで再抽出をくり返す。得られたアセトン畭燥粉末を正確に秤量し， $50 \mathrm{mg}$ 当り $1 \mathrm{ml}$ の $0.025 \mathrm{M}$. のア ンモニア液を加え， $0{ }^{\circ} \mathrm{C}$ で 1 時間抽出したあと， 3000 迴転 15 分間遠沈して得た上澄首を enzyme として Korn $^{28)}(1959)$ の方法によつて FFA を測定し，incubation による FFA の增加量を求め， 1 時間当り 100 $\mu \mathrm{eq} / 1$ の FFA 增加を示めす酵素活性を 1 単位とし, 湿重量 $1 \mathrm{gr}$ 当りに換算した.

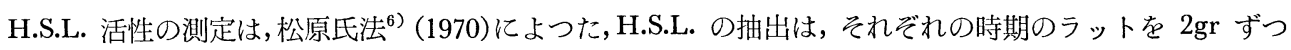
として，5\% BSA を含有する Krebs-Ringer phosphate buffer（pH 7.4) 5ml を入れた 50ml Erlenmyer 型フラスコに投入し， metabolic shaker で $37^{\circ} \mathrm{C} ， 30$ 分間大気中にて振盪し，まず preincubation を行なう. その後, 組織片をとり出しトーションバランスにより科量したあと, 承冷 sucrose 溶液を加え氷冷しながら Potter-Elvehjem 型 homogenizer で 2 分間, homogenize し, $4{ }^{\circ} \mathrm{C}, 12000 \times \mathrm{g}$ の条件で 10 分間遠沈して 上清を採取した。 この上清に H.S.L.が抽出されているが，H.S.L. 活性の測定は次の如くした。即ち，有栓 試験管中に抽出液 $0.2 \mathrm{ml}$ をとり，Fatogen $0.1 \mathrm{ml} １ \mathrm{~N} \mathrm{KOH} \mathrm{で} \mathrm{pH} 6.8$ 亿調整した 20\% BSA solution $0.5 \mathrm{ml}, \mathrm{pH} 6.8$ の $0.06 \mathrm{M}$ phosphate buffer $0.2 \mathrm{ml}$ を混じ再蒸溜水で全量を $2.0 \mathrm{ml}$ としたあと, $37^{\circ} \mathrm{C}$ 水溶 液中で60分間 incubation し，それぞれの medium 中に遊出される FFA を Dole の方法によつて測定し， incubation 前と後の両測定值の差から酵素活性を計算した。

\section{B. 実験成績}

1. HPL を直接胎仔に投与した際の妊娠ラットならびに胎仔における glucose, FFA, TG および T-N 量の変化について

HPL の直接胎仔投与群および非投与群の妊娠ラット血清中の glucose, FFA 量の変化は Fig. 13 亿示す. HPL 直接胎仔投与前と投与後 4 時間目のものを比較すると glucose 量の軽度の減少と FFA 量の軽度の上 昇がみられたのみである。

一方, hPL 直接胎仔投与群および非投与群の glucose, FFA, TG ならびに T-N量を, Fig. 14 亿示すが, glucose, FFA, TG ならびに T-N 量は, hPL 直接胎仔投与群と非投与群の間に有意差はみられなかつた.

\section{2. 胎仔 carcass ならびに新生仔における両 Lipase 活性の検討}

$\mathrm{L}_{21}$ の時期の胎仔, 婏出直後の新生仔, 生後10日目の新生仔ならびに 3 ケ月目のラットおよび老鼠の L.P.L. と H.S.L. の活性は, Table 6 亿示す. $\mathrm{L}_{21}$ の胎仔の L.P.L. 活性は $11.3 \mathrm{U} / \mathrm{gr}$ であるが，新生仔では胎仔 の約 2 の活性をしめし，10日目新生仔では胎仔の約 3 倍と活性の克進がみられた.

一方, H.S.L. 活性は, L.P.L. 活性と同様に新生 仔では胎仔の約 2 倍で $10.1 \mathrm{U}_{/} \mathrm{gr}, 10$ 日目の新生仔で は様 3 倍と高くなつていた。

\section{G. 小括之考按}

弤娠ラットに hPL を連続投与するてとによつて, その胎你の発育が30\%以上にも京進するというとと の原因は，hPL の妊娠個体（母体側）における lipolytic な作用に起因するものであろうと推察した が，hPL が直接胎児という「場」においてその発育 になんら影響をおよぼさないのかという疑問が残る。

そてで著者は妊娠末期にラットを開腹し, 胎仔に 直接 hPL を投与し，その後，hPL の投与をうけな かつた他側子宮角内胎仔と，投与をうけた胎仔の glucose, FFA, TG ならびに T-N 量を比較検討し た. その結果，hPL を妊娠ラットに投与した際に みられたような glucose, FFA, TG ならびに T-N などの量的な変化は，hPL 直接投与胎仔や非投与
Fig. 13. Contents of FFA and glucose in the serum. (Pregnant rats in Wistar strain)

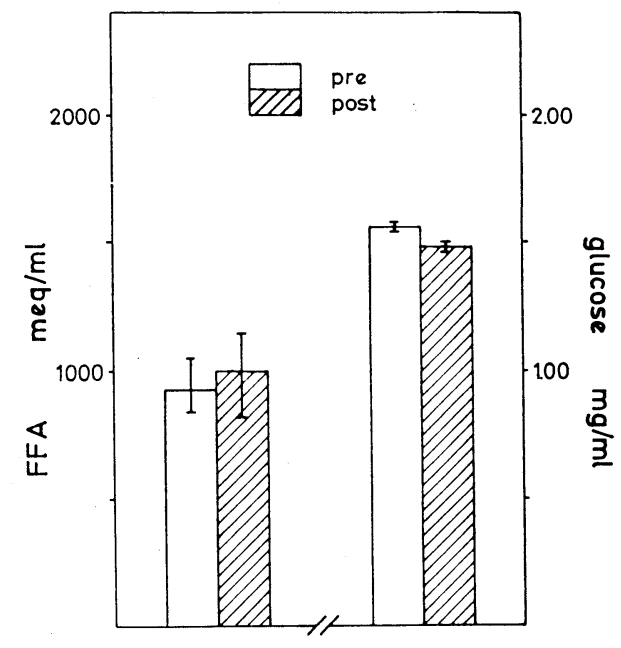


Fig. 14. Contents of total nitrogen (TN), triglyceride (TG), glucose and FFA in the carcass after direct administration of hPL to the foetus in utero. (in Wistar strain)

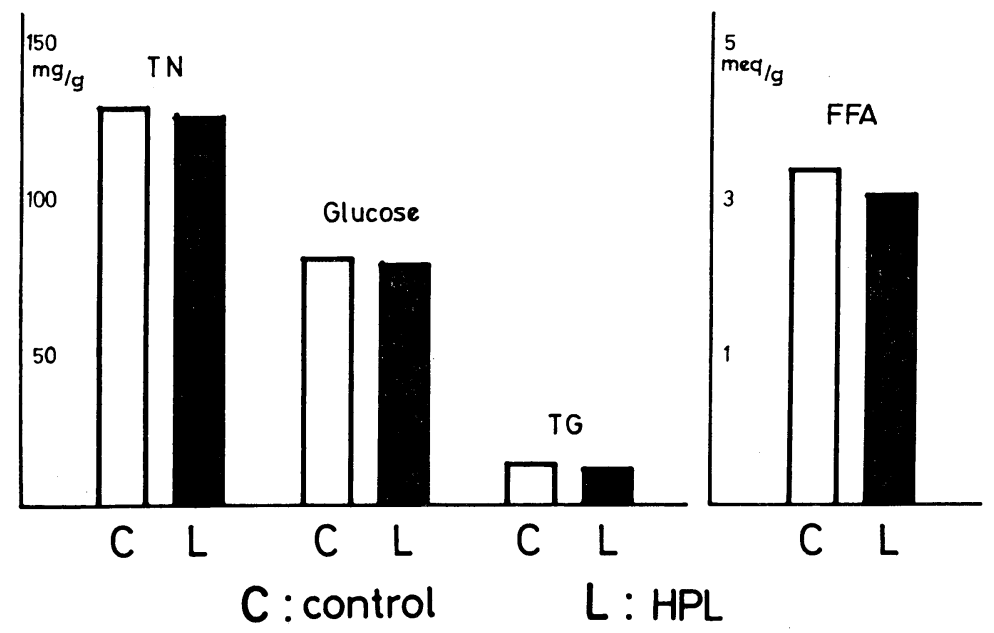

胎仔さらにはての実験条件下での母体において全く 認められなかつた。

また著者は，胎仔ならびに新生仔期のラット carcass の L.P.L. および Lipase 活性を同時に測定し てみたが，両 Lipase の活性は生後急激な上昇傾向 を示したのに反し，胎仔の両 Lipase 活性は，きわ めて低いという成績を得た。

以上の成績から考学ると, hPL は feto-placental unit そおいてその生物作用を発揮せず, placentomaternal unit そおいてのみ有效働き，その作用 にもとづいて間接的に胎児の発育に関与し，母体由来の同化資材を提供する因子であると思われる.

\section{IV. 綜 括 亡考按}

HPL のもつ主として二つの生物学的作用から，本物質の妊娠個体における意義を論ずる場合，プロラク チン (hPRL) 様作用に目を向けると, Ito ${ }^{25)}$ (1961), Josimovich ${ }^{26)}$ (1961), Friesen ${ }^{16)}$ (1965), Florini ${ }^{15)}$ (1966), Turkington and Topper ${ }^{35)}$ (1966) や Prop ${ }^{32)}$ (1967) らの報告からでもわかるように，hPLは「乳汁分泌促進 亿働くよりはむしろ乳腺の発育を促す」ようである。しかしながら，hPL のての作用は単独ではかなり弱 く，インスリンやステロイドホルモンなぞ他のホルモンそ協調してはじめて乳腺への作用を発揮するものの ようである.

ところで妊婦血中の hPRL の量的な動態を RI によつて検討した Friesen ${ }^{18)}$ (1972) の最近の報告によ ると妊娠初期に $50 \mathrm{ng} / \mathrm{ml}$ であつた hPRL は, 妊娠未期では約 $250 \mathrm{ng} / \mathrm{ml}$ と増加しており, その娃娠経週 的パターンは，末期に向つての漸増傾向を示している．Friesen は妊娠中に増量する hPRL の意義を分婏 後の乳汁分泌汶対する準備として，妊娠中に認められる他の mammotropic factor と共同してまず乳腺の 発育を促進するものであり，また妊娠時の sodium homeostasis を維持するものであろうと説明している. ところが，娃娠時のこの hPRL のパターンは，我々の測定した hPL の妊娠経週的な上昇のパターンとき 
わめて類似しているので，彼の使用した RI-hPRL 系が純化されてないのではないのでないかという䯚念 もある. しかし，蛋白化学的な知見からみた hPL は，hPRL とは類似せず，かつ免疫学的にも全く交叉性 を有さないとてろから, 両者はまつたく別俔の蛋白ホルモンと考元られ, 從つて, 両者の妊娠時のとのよう な動態から判断すると，妊娠洔における乳腺の発育には hPL の働きが主役であるのか，あるいは hPRL の働きが主役であるのかという問題になると，Freisen のいう様には説明が出来ない.

そてで著者は，hPL の妊娠個体における意義を，hPRL 様作用からではなくて，hPL が蛋白化学や免废 化学の立場からみて hPRL よりはむしろ, hGH と類似しているとてろから本物質について hGH アナロ 一グの作用を検討し，それらの成績をもとにして，弤娠時における hPL の意義を妊娠個体における「代謝 調節ホルモン」としてのあり方から考えてみた.

さて教室村田は，hPL の固有の生物学的作用を検討する意味で，Wistar 系ラットの glucose fatty acid cycle 亿与える影響や in vitro でのラット副てう脂内 H.S.L. や L.P.L. 活性におよぼす hPL の影響を検 討し, hPL は被検動物血清中の FFA 量の增加を苾起し, かつ副とう脂の両 Lipase の活性を共に元進させ るというような脂肪分解作用をもつととを明らかにした。

このような hPL の脂肪分解作用は, Grumbach ${ }^{19)}$ (1966) らも確認しており，しかも彼は，hPL の脂肪分 解作用は，必ずしも hGH の協調作用を必要とせず，hPL 自身にその hormonal action としての脂肪分 解作用があるものであると主張している。

そてで著者は，ての hPL の脂肪分解作用が，妊娠個体において胎児の発育にどのように影響するかとい うととを，まず，妊娠ラットに hPL を連続投与し，その胎仔の発育におよぼす影響から検討してみた。

その結果，弤娠ラットに hPL を連続投与すると，母血清中の glucose, FFA, TG ならびに T-N 量は 有意に増加し, かつ, それにつれて胎仔の発育も促進されるという興味ある成績が得られ, また胎仔の体重, 各藏器の glycogen 量ならびに胎仔 carcass の glucose, FFA, TG ならびに T-N 量には, hPL の投与量 との間に dose response 的な增加関係がみられた。また，妊娠初期から hPL を投与するよりは，娃娠中期 から末期にかけて投与する方が，てれらの物質の量的な增加や胎児の発育に対してより効果的であるてとも わかつた。

さらに，あらかじめ脂肪組織を標識しておいた弤娠ラットに hPL を投与すると，血中 $\mathrm{C}_{14}$-FFA 量の増 加とともに，脂肪組織では $\mathrm{C}_{14}$ - $\mathrm{TG}$ 量の蓄積が充進すること，また胎仔では母体でのてれらの動きに伴つ て, 著明な $\mathrm{C}_{14}$ - $\mathrm{FFA}$ と $\mathrm{C}_{14}$ - $\mathrm{TG}$ ならびに cold $\mathrm{FFA}$ 量の増加が認められた。

一方， $\mathrm{C}_{14}$-D-glucose を母体に投与した後, hPL を母体に投与すると,母血清中の cold glucose 量は増加 するが， $\mathrm{C}_{14}$-glucose 量は逆に減少し，胎仔では cold glucose および $\mathrm{C}_{14}$-glucose 量の著増が認められた。

つまり，hPL を妊娠ラットに弤娠中期から末期にかけて連続的に投与するてとによつて，母体に惹起さ れた glucose-fatty acid cycle の変化が，胎仔の発育を促進するという興味ある成績が得られたのである。

また著者は，胎仔の発育に対する hPL の直接的な作用を検討する意味から，直接胎仔に hPL を投与し， その後の胎仔の glucose, FFA, TG ならびに T-N 量と，母体のそれらについて検討を加えた。 その結果, hPL の直接投与をうけた胎仔と非投与群胎仔間では，乙れらの物質の量的な変化に差はみられず，また胎 仔に hPL を直接投与しても母体におけるてれらの物質の動きには全く影響が認められなかつた。

以上の二つの実験から，少くとも以下のことが推察されるようである.

その一つとして, hPL は feto-placental maternal system のうち, feto-placental unit ではその生物作 用を発揮し難い.

その二は, hPL は placenta-maternal unit おいてのみその生物作用を発揮し, その作用に基づいて間接 的に胎児の発育が促進されるというととである.

さて, hPL を弤娠ラットに投与した際にみられた血中の FFA 量の著增と, 脂肪組織における再エステル 化の充進という現象は, 村田がすでに報告した hPL によつて活性化される両 Lipase 活性の充進状態に差 がみられるてと,つまり脂肪組織内の H.S.L. 活性は, hPL 投与後きわめて短時間で急上昇し, しかもその 
活性亢進の立ち上りは，L.P.L. 活性のそれよりも早く，また数時間後には H.S.L. 活性は降下傾向をしめす のに, lipogenic action をもつ L.P.L. 活性は数時間後でもむしろ漸增傾向をしめしているという両 Lipase 活性の㠵進パターンの相違や，hPL 投与によつて脂肪組織への glucose uptake がたかまり，さらには insulin 分泌の增加がみられたといら成績を考光併せると，hPL はまず脂肪組織内の H.S.L. 活性を九進さ せて脂肪分解作用を促進する。乙の場合 glycero-phospho-kinase のない脂肪組織では, glucose uptake の たかまりと共に糖代謝が活発となり， $\alpha$ ーグリセロリン酸が増加する結果, 再エステル化すなわち TG の合 成がたかまるものと考光られる。

また，妊娠個体のもつ glucose-fatty acid cycle が，hPL の投与によつて FFA 優位の状態になると， 筋肉の glucose uptake は逆に減少し, インスリン感受性が低下する一方, 筋肉組織のエネルギー源は, FFA 亿依存するようになると考学られ，その結果，血中には当然 glucose が過剩となるものと思われる.

さて，乙のように hPL によつて增加した舟血清中の FFA と glucose の胎児への移行については，す でに Van Duyne et $\mathrm{al}^{36)}$ (1962), Chen et $\mathrm{al}^{10)}$ (1965) らの脂肪酸の胎览への転送や, Davies, J. ${ }^{12)}$ (1958) ら の glucose の転送, さらには Page et al ${ }^{31)}$ (1957) や Dancis ${ }^{11)}$ (1962) のア之ノ酸の Stereo-specific active transport などに関する報告もあるが，著者の実験成績からでもわかるように，胎仔の FFA と glucoseの 量は母体のてれらの物質の動きに平行しているようであり, しかも glucose の胎児への転送は, hPL の投 与によつてきわめて充進するようでもある。

とてろで, 胎児の発育はてれらの物質の胎児への転送のいかんによつて明らかにコントロールされている ようであるが，妊娠初期から hPL を妊娠ラットに投与するよりはむしろ，妊娠中期から投与する方が，胎 巟の発育に対してより効果的であつたという著者の成績は, Claud A. Villee, PH. D. ${ }^{37)}(1970)^{38)}(1953)^{39)}$ (1954) の妊娠初期胎盤では glycogenesis 亿働らく glucose-6-phosphatase 活性が高まつているが, 胎児の 発育時期である弤娠中期以後になると, glucose-6-phosphatase 活性はむしろ低下し, citric acid cycle や pentose phosphate pathway あるいは glycolysis 亿働らく酵素の活性がたかまつているとと, また胎先に おいては母体より充分に glucose の供給をうけている時には，glyconeogenesis 亿関する酥素の活性は低く， 逆に glycokinase, pyruvate kinase など glycolysis に働らく主たる酵素の活性が方進しているという Hahn， P. ${ }^{21)}$ (1968), Burch, H.B. ${ }^{9)}$ (1963) らの報告や，また glucose の供給が不充分になると glyconeogenesis に 働らく酵素の活性が逆に立進するのだという Hahn，P. ${ }^{20)}$ (1970)などの報告を考えると，hPLによつて惹起さ れた過剩の glucose は, 妊娠中期以後の胎児においては glycogen として蓄積されるよりは, むしろ胎児の 発育のための重要なエネルギーとして利用されていると可能性がきわめてたかい. しかし，hPL はラット に対しては異種蛋白であるので, その長期投与により抗体の生成がおてり，てれにより hPL 本来の生物学 的作用がある程度相殺されてしまつた可能性もあり，てのととについては将来検討しなければならない.

また, 胎児肝臟では glucose-6-phosphatase 活性が妊娠中期より急上昇するてとや, Shelley ${ }^{33}$ (1966)の婏 出前の胎児では glycogen synthetase や phosphoglucomutase などの glycogen syntnesis に関する他の酵 素活性の充進のために, glycogen の蓄積が元進するといつた報告からみると，hPL の投与をうけた妊娠う ットの末期胎仔では, 過剩の供給をうけている glucose は, 肝藏で FFA が glycolysis を抑制するてとに よつて, glycogen として肝蔵に多量に蓄積され，てれが分婏後の胎児の予借能に重大な影響を与えている ととも推察される.

一方, あらかじめ妊娠ラットの脂肪組織を， $\mathrm{C}_{14}$-oleici acd で標識しておいたあと, hPL を投与すると, 胎仔に高い $\mathrm{C}_{14}$-FFA と $\mathrm{G}_{14}$-TG の蓄積がみられたが，乙の現象は胎仔で lipolysis に働らく H.S.L. の活 性がきわめて低く, 逆に acetyl Go A carboxylase 活性が光進しているてとや，てのような胎仔にみられる より旺盛な解糖系からの $\alpha$ ーグリセロリン酸の増量などによつて, 母体から転送された FFA は, 胎仔にお けるエネルギー源として利用されるよりはむしろ，速やかに TG へと合成されてゆくためであろう。

また，蛋白合成も Lister ${ }^{29)}$ (1961) や Thomson and Hytten ${ }^{34)}$ (1960) らによると，妊娠後半期の胎児では， 特に旺盛となるが, 著者の実験においても hPL 投与群胎仔の T-N 量は, 非投与群胎仔のそれよりもはるか 
に高いという成績が得られている。

いずれにしても，hPL 投与妊娠ラットの胎仔で は，全体的な代謝の傾向は非投与群胎仔のそれより も同化作用の結果がきわめて著明であるといえる.

以上の如き胎児の代謝に関する諸家の報告や，著 者のこれまでの成績から妊娠個体における hPL の 意義を「代謝調節ホルモン」としての立場からみる と Fig. 15 の如く考えるととが出来る.つまり， hPL は妊娠時の母体の糖脂質代謝に影響をおよぼ し, その結果母体側に過脂血や過血糖が惹起され, 母体のエネルギー源は遊離脂肪酸に依存する一方, 胎盤を介してそれらが胎呪に転送され，糖質は主と して胎児でのエネルギー源として利用されるが，遊 離脂肪酸は解糖系からの多量の $\alpha$ 一グリセロリン酸 と合して中性脂肪として合成され，さらに胎盤を通 過したアミノ酸は解糖系からの水素イオンを利用し て，あるいは胎児自身のインスリンや生長ホルモン の作用と相いまつて旺盛な蛋白合成に関与する。

つまり，hPL は母体への作用にもとづき間接的に胎韭の発育に対してきわめて有意義な同化資材を絶え間 なく提供しているものと考えられ, さらに胎児固有の同化的性格もてれらの物質の増量によつて, より京進 するものと思われる.

結 語

妊娠時における hPL の意義は, その固有の生物学的性格の一としての lipolytic action を中心とした 「代謝調節ホルモン作用」にあり，しかもその作用は placental maternal unit においてのみ発揮され，か つその作用に基づいて，間接的に胎仔の発育に対してきわめて有意義な同化資材を絶え間なく母体側から提 供するものと考えられる.

なお，本論文の要旨は，第四十五回日本内分泌学会（東京・1972）, 第四回国際内分泌学会（ワシントン D. G. 1972) および Rockféller 大学における Seminar (N.Y. 1972) において発表した.

謝

辞

稿を終るに臨み，御指導御校閲をいただいた恩師東條伸平教授に梁謝致します。また直接御指導御鞭達を いただいた望月真人講師および教室の蛋白ホルモングループの諸兄姉に感謝し, 種々御援助いただいた神戸 大学第二内科新光毅講師, 中田晃博士，龟野靖郎先生をはじめとする諸兄に感謝致します.

また，hGH の提供をしていただいた NIA. NIAMD R.W. Bates ならびに National Pituitary Agency の A.E. Wilhelmi 博士に感謝します.

1）東條伸平, 望月真人, 村田孝美, 森川 肇, 都倉康正, 水沢富一, 椋田 享 : 臨床婦人産科, 23, 1027, 1969. 2) 望月真人，村田孝美，森川 肇，椋田 享，東條伸平：日産婦誌，22，245，1970.

望月真人, 森川 肇, 岡部桂一郎. 曺 洙鎔, 東条伸平：日産婦誌, $23,320,1971$.

4）望月真人,

森川 肇, 椋田 享, 曺 洙鎔, 東條伸平：日産婦誌，23，450, 1971.

5）中田 晃: 神大医紀要, 31, 106, 1969.

6）松原嘉雄 : 日内泌誌，46，163，1970.

7）望月真人，森川 肇，村田孝美，

椋田 享, 東條伸平: 日産婦誌, $22,245,1970$.

8）村田孝美：日内泌誌，48，6，1972.

9) 
Burch, H.B. : Ann. N.Y. Acad. Sci., 111, 176, 1963. Mccann, M.L. and Schwartz, R. : Pediatrics 36, 843, 1965. Gynec., 84, 1749, 1962. 12) Davies, J : Proc Soc Ex

10) Ghen, C.H., Adam, P.A., Laskowski, D.W., 12) Davies,

11) Dancis, J. : Amer. J. Obstet. Dole, V.F. : J. Clin. Invest., 35, 150, 1956.

14) Fletcher, M.J. : Glin. Ghem. Acta, 22,393 1968. 15) Florini, J.R., Tonelli, G., Breuer, C.B., Coppola, J., Ringler, I. \& Bell, P.H. : Endocr., 79, 692, $1966 . \quad$ 16) Friesen, H.: Endocr., 76, 369, $1965 . \quad$ 17) Friesen, H.G. : Endocr., 79, 212, 1966. 18) Friesen, H. et al. : Growth and growth hormone (Editors : A. Pecils and E.E. Muller), Excerpta Medica, Amsterdam, 234, 1972.

19) Grumbach, M.M., Kaplan. S.L., Abrams. G.L., Bell, J.J., Conte, F.A. : J. Glin. Endocr., Metab. 26, 478, $1966 . \quad 20)$ Good, G.A., Kramer, H. \& Somoggi, M. : J.B.C., 100, 485, $1932 . \quad 21)$ Hahn, P., \& R. Greenberg : Experientia, 24, 428, 1968. 22) Hahn, P.D. Sc. : Fetal growth and Development (Edited by Harry A. Waisman and George Kerr), McGraw-Hill, 297, 1970.

23) Hoffman, W.S. : J. Biol. Ghem., 120, 51, 1937. 24) Hoffman ならびに Auto Analyzer Technicon Laboratory 法: Technicon Auto Analyzer Methodology, method file N-9a, $1965 . \quad$ 25) Ito, Y. and Higashi, K. : Endocr. Jap., 8, $279,1961$. 26) Josimovich, J.B. and MacLaren, J.A•: Endocr., 71, 209, $1962 . \quad 27)$ Koch, F.G., and Hanke, M.E. : Practical Methods in Biochemistry, Williams and Wilkins (Baltimore), $1948 . \quad 28$ ) Korn, E.D. : Method of Biochemical Analysis, 7, $1959 . \quad 29)$ Lister, U.M. : J. Obstet. Gynec., Grit. Gomm., 68, 405, 1961. 30) Morikawa, H., Mochizuki, M. and Tojo, S. : Endocr. Jap., 18(5), 417, 1971. 31) Page, E.W., Glendening M.B., Margolis, A. and Harper, H.A. : Amer. J. Obstet• Gynec., 73, 589, 195\%. 32) Prop, F.J.A. : Protein and Polypeptide Hormone, Part II, Excerpta Medica Foundation, 508, $1967 . \quad$ 33) Shelley, H. and H. Neligan : Brit. Med. Bull., 22, 34, 1966. 34) Thomson, A.M. and Hytten, F.E. : Proc. Nutr. Soc., 19, 5, $1960 . \quad 35)$ Turkington, R.W. and Topper, Y.J. : Endocr., 79, 175, 1966. Amer. J. Obstet. Gynec., 84, 1069, 1962. 36) Van Duyne, G.H., Havel, R.J. and Felts, J.M. : 37) Villee, G.A. Ph. D. : Fetal growth and Development (Edited by Harry A. Waisman and George Kerr), Mc Graw.Hill, 11, 1970. 38) Villee, C.A. : J. Applied Physiol. 5, 437, 1953. 39) Villee, C.A. : Cold Spring Harbor Symposia on Quant. Biol., 19, 186, 1954.

日本内分泌学会雑誌 第48巻 第 9 号 昭和47年12月15日印刷 昭和47年12月20日発行 （毎月 1 回発行） 1 年金 3500 円

発行所 日本内分泌学会（振替京都12902番） 京都市上京区河原町通広小路上ル梶井町456 京都府立医科大学第一内科教室内

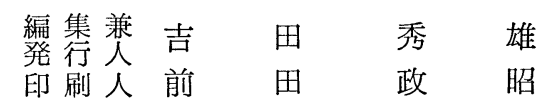

印 刷 所 株式会社前田進行堂印刷所 京都市中京区西ノ京南上合町81 